\title{
MEGKÜZDÉSTÖRTÉNET
}

\author{
Kulcsár BeÁtA*
}

\section{Hazatérés Kanadából 1929-ben: deportálás három látószögböl}

1929. május 13-án a kanadai Battleford elmegyógyintézetébe (Battleford Mental Hospital) felvettek egy zavart tudatú magyar cipészt, Darab Józsefet. A kórházi jelentés szerint a férfi, akit Prince Albertből (Saskatchewan tartomány) szállítottak a kórházba, egy-két nappal korábban ollóval megpróbálta leszúrni a feleségét. A kísérlet nem sikerült, mivel a nő kiáltozni kezdett, és a segítségére siettek. A férj azzal magyarázta tettét, hogy az asszony fenyegetően viselkedett, azt mondta neki, nem fogja megérni a reggelt. Az eset megtörténtekor a férfi már két-három napja zavart volt, az a képzet gyötörte, hogy valaki az életére akar törni, még a feleségére is gyanakodott. ${ }^{1}$ A pszichiátriára internált férfi hónapokon keresztül az intézmény lakója maradt. A történtek nyomán a kanadai bevándorlási minisztérium vizsgálatot indított, melynek eredményeként a hatóságok még ebben az évben Magyarországra deportálták ${ }^{2}$ Darab Józsefet és Darab Józsefnét.

A házaspár nem túl hosszú kanadai tartózkodása 1927-1928-ban kezdődött; ezekben az években vándoroltak ki külön-külön Északkelet-Magyarországról Kanadába, ${ }^{3}$ ahol a préritartományok (Prairie Provinces) egyikében, Saskatchewanban telepedtek le, és fogtak hozzá az egzisztenciateremtéshez. Darabék a második, egyben a legnépesebb magyar bevándorlási hullámmal (1924-1930) érkeztek. ${ }^{4}$ Saskat-

\footnotetext{
* A szerző az Eötvös Loránd Tudományegyetem Bölcsészettudományi Karának tudományos segédmunkatársa. E-mail: kulcsar8beata@gmail.com

1 MNL OL K 139 (Winnipegi Konzulátus), 13. csomó, 1931, 1. tétel, 3222/D, 55.

2 A „deportálás” (deportation) szó a kanadai bevándorlási törvényekben szerepel; a korabeli kanadai és magyar hatóságok egyaránt használták a bevándorlókkal szemben kezdeményezett kiutasítási, kitoloncolási eljárásokra.

3 A tengerentúli magyar bevándorlók fó származási helye éppen ez az északi, északkeleti régió volt. L. Puskás Julianna: Migráció Kelet-Közép-Európában a 19. és 20. században. Regio, 1991/4. 26. és Puskás Julianna: Kelet-Európából az USA-ba vándorlás folyamata 1861-1924. Történelmi Szemle, 1984/1-2. 158-159.

4 A második hullámmal 25-28.000 magyar érkezett Kanadába. L. Patrias, Carmela: Patriots and Proletarians. Politicizing Hungarian Immigrants in Interwar Canada. Montreal:
} 
chewan egyáltalán nem volt ismeretlen a magyarok körében, ugyanis az I. világháború előtt - Magyarországról és az Amerikai Egyesült Államokból - Kanadába áramló magyar népességnek éppen a saskatchewani régió volt az első célpontja, a legelső magyar kolóniák, települések itt jöttek létre. ${ }^{5}$ Mivel a kanadai hatóságok a prérire, a nyugati területekre irányították a bevándorlókat, a második hullám magyar bevándorlóinak egy része szintén Saskatchewanban „kötött ki”. A tartománynak a Darab-házaspár által választott északibb részén, Saskatoon és Prince Albert környékén az 1900-as évek elején jelentek meg magyarok. ${ }^{6}$ Saskatchewanban 1921-ben még csak 8.946 magyar élt, 1931-ben már 13.363 fö. ${ }^{7}$ A magyar népességnek az 1920-as években lezajlott kanadai bevándorlását - az amerikai és a kanadai bevándorláspolitika ${ }^{8}$ mellett - főként a gazdasági világválság előtti mezőgazdasági konjunktúra, a kanadai gabona iránti világpiaci kereslet alapozta meg. A fellendülés elsősorban a fejlődő közlekedési és piaci hálózatokra, valamint a farmokon folytatott családi jellegü gazdálkodásra épült. ${ }^{9}$ A betelepülő magyarok nagy többsége földműves volt, az 1928-1930 között érkezők 0,91\%-át tették ki a kézmüvesek, a kisiparosok. ${ }^{10}$

Tanulmányomban Darab József és Darab Józsefné deportálásának előzményeit, okait, folyamatát és élményeit rekonstruálom, az ügy érintettjeinek - a házaspár, a magyar konzul és a kanadai bevándorlási hatóságok - egymástól eltérő látószögei és tapasztalatai alapján. A kérdés tehát az, mi is történt pontosan, miért és hogyan zajlott le a házaspár kitoloncolása, továbbá hogyan élték meg az egyes szereplők a történteket, hogyan küzdöttek meg a kihívásokkal, és hogyan próbálták érvényre juttatni saját elképzeléseiket, érdekeiket a deportálási eljárás során. A részletekre és a totalitásra egyaránt érzékeny rekonstrukciós kísérlet legalább három szinten hasznosul: teljes áttekintést ad az esetről, és elénk tárja az

McGill-Queen's University Press, 1994. 235. és 237.; Dreisziger F. Nándor: Years of Growth and Change, 1918-1929. In: uö: (ed.): Struggle and Hope. The Hungarian-Canadian Experience. Toronto: McClelland \& Stewart, 1982. 100.

5 Kovács, Martin L.: The Saskatchewan Era 1885-1914. In: Dreisziger F. Nándor (ed.): Struggle and Hope. The Hungarian-Canadian Experience. Toronto: McClelland \& Stewart, 1982. 6193.; Ruzsa Jenő: A kanadai magyarság története. Toronto: Ruzsa Jenő ev. lelkész, 1940. 82-123.

6 Kovács, 1982, 66.

7 Kósa, John: Land of Choice. The Hungarians in Canada. Toronto: University of Toronto Press, 1957. 5. 1921-ben a kanadai magyarok többsége még Saskatchewan tartományban élt, 1931-ben már Ontarióban voltak a legtöbben. A munkaerőt vonzó iparosodottabb Ontario elönye tovább nőtt a későbbiekben.

8 Az Amerikai Egyesült Államok az 1920-as évek első felében törvények (1921, 1924) útján, kvótarendszer segítségével jelentős mértékben korlátozta a bevándorlást. Kanada ezzel szemben 1930-ig nyitva volt az európai agrárnépesség számára, így módosult a kivándorlás iránya. Kanada mellett Argentína és Brazília is gyakori kivándorlási célpont lett.

9 Friesen, Gerald: The Canadian prairies: a history. Toronto: University of Toronto Press, 1987. 301., 329.

10 Patrias, 1994, 236. 


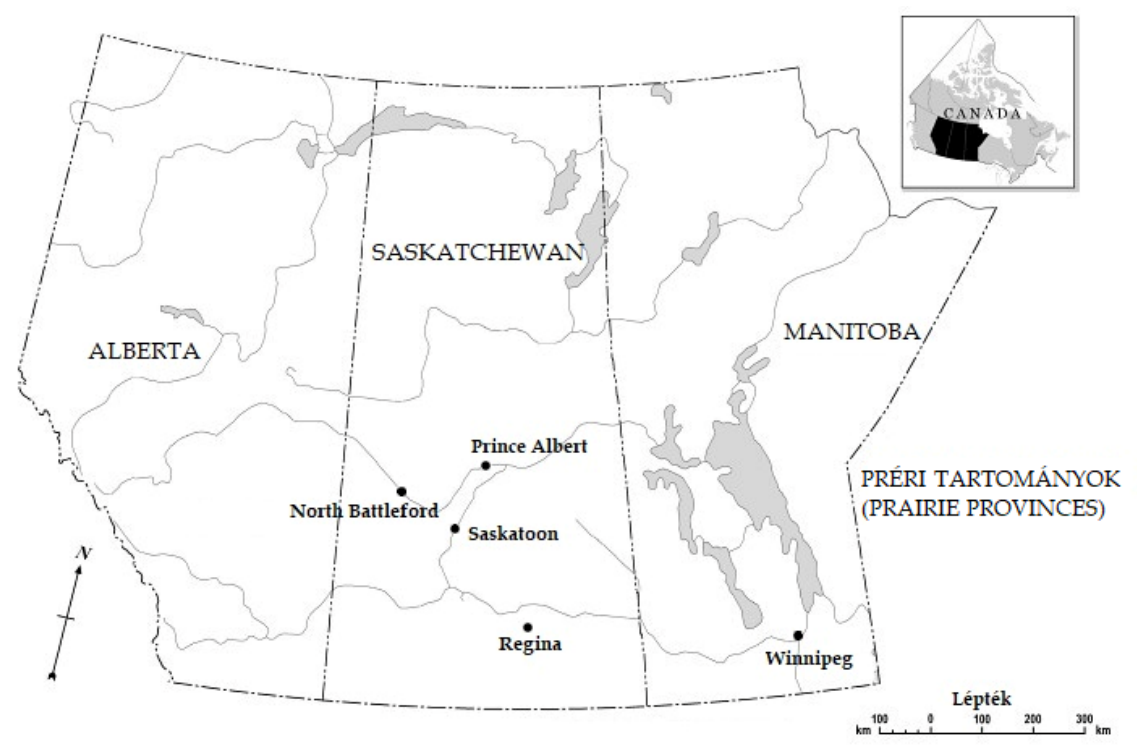

ügy részleteit, összefüggéseit; megismerteti az egyes szereplők élményeit, megküzdési technikáit; illetve betekintést enged a korabeli általánosabb jelenségekbe is, a bevándorlók stresszkezelési stratégiáiba, a deportálási eljárás folyamatába, szabályaiba, a kanadai bevándorláspolitikába vagy a magyar konzul szerepkörébe, szerepfelfogásába. Az írás a mikrotörténelem módszertana szerint készül: egyetlen esetet elemzek részletesen, de általánosabb jelenségek, problémák iránti érdeklödéssel. A rekonstrukciós vizsgálat forrásbázisát a winnipegi magyar konzulátus jó állapotban fennmaradt iratgyüjteménye (MNL OL K 139) képezi, elsősorban az a dosszié, mely a Darab-házaspár ügyéhez kapcsolódó iratokat - mindenekelőtt a felek közti levélváltások dokumentumait - tartalmazza.

\section{A házaspár látószöge}

Darab József 1895. április 4-én, Darab Józsefné (szül. Jelenik Julianna) 1899. november 28-án született, mindketten Sárospatakon. Innen vándoroltak ki Kanadába. A Zemplén vármegyei alispáni hivatal 1927 januárjában és 1928 februárjában állított ki útlevelet számukra. ${ }^{11}$ Először - jellemző módon - a férfi hagyta el Magyarországot, és 1927. április 9-én Halifaxban, a Lancastria nevü hajó fedélzetéről

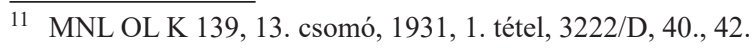


szállt partra. A felesége 1928. május 3-án az Ascaniával érkezett Quebecbe. ${ }^{12}$ A nő később azt állította, hogy kivándorlásuk előtt mindenüket eladták. ${ }^{13}$

A férfi kezdetben egy barátja, bizonyos Steve Suette farmján (Saskatchewan) dolgozott több mint egy évig. ${ }^{14}$ Az Északi-Saskatchewan folyó partján lévő Prince Albertbe valószínűleg azután költözött, hogy felesége is megérkezett Kanadába. ${ }^{15}$ Itt már cipészként tevékenykedett, felesége pedig varrónőként dolgozott. Jövedelmi helyzetükről nem tartalmaznak pontos adatokat a források, különösen a férj bevételei maradnak homályban, az azonban valószínüsíthető, hogy az asszony varrónői tevékenysége révén értékelhető jövedelemhez jutottak. A dokumentumok alapján nem teljesen egyértelmü az sem, hogy az a ház, amiben laktak, a házaspár vagy csak a feleség tulajdonában volt-e. Az otthon eladott javakból származó pénzt részben ebbe az ingatlanba fektethették. Nehéz rekonstruálni, hogy milyen tervekkel érkeztek Kanadába. A nő szerint az volt a céljuk, hogy a megkeresett pénzből egy kanadai farmot vásároljanak, tehát a városi kisiparosi életet - ha hihetünk neki - átmenetinek tekintették. ${ }^{16} \mathrm{~A}$ férfi elmezavara azonban kizökkentette öket terveik megvalósításának folyamatából.

Kettejük közül elsősorban a feleség látószögéből láthatjuk az eseményeket, mivel a konzulátusi dossziéban fennmaradt levelek tőle származnak. Ö azonban föként kettejük nevében nyilatkozott, a férje álláspontját és érdekeit is reprezentálta. Levelei a deportálással szembeni küzdelem ,jegyében” születtek, és a deportálás elkerülésére irányultak.

Darab Józsefnének a deportálás miatti fenyegetettségre adott reakciói leírhatók a megküzdés fogalmával, amit rendszerint az átlagosnál fokozottabb megterhelés viszonyai között alkalmazott kontrollkísérletekre szoktak használni. A megküzdés célja a megterhelő viszonyok miatti egyensúlyvesztés, bizonytalanság- és stresszérzés kezelése, csökkentése. A szakirodalomban legtöbbet idézett és legáltalánosabban elfogadott definíció szerint „megküzdésnek tekinthető minden olyan kognitív vagy viselkedéses erőfeszítés, amellyel az egyén azokat a külső és belső hatásokat próbálja kezelni, amelyeket úgy értékel, hogy felülmúlják vagy felemésztik

12 MNL OL K 139, 13. csomó, 1931, 1. tétel, 3222/D, 55.

13 MNL OL K 139, 13. csomó, 1931, 1. tétel, 3222/D, 60.

14 A konzulátusi dossziéban nincs adat Steve Suette személyéről és arról, hogy hogyan kerültek kapcsolatba egymással.

15 Prince Albert számára az 1927-1929 közti időszak jelentősnek bizonyult a bevándorló népesség bővülése és az urbanizálódás szempontjából. Az 1920-as évek végén a vasúti hálózat fejlődésének új szakaszához érkezett, egyre több települést kapcsoltak össze Prince Alberttel. L. Abrams, Gary William David: Prince Albert: the First Century 1866-1966. Saskatoon: Modern Press, 1976. 271-273.

16 ,.... ha mi is el érjük a célunkat mi is farmon akarunk élni.” MNL OL K 139, 13. csomó, 1931, 1. tétel, 3222/D, 35. 
aktuális személyes forrásait". ${ }^{17}$ Vagyis a megküzdés során az egyén a külvilágból érkező fenyegetésekre és a belső feszültségekre reagál, és komfortérzete növelése érdekében a saját viselkedését és gondolatait, ezáltal az érzelmeit szabályozza, irányítja. ${ }^{18}$ Darab Józsefné esetében viselkedéses és kognitív megküzdési erőfeszítésekkel egyaránt találkozhatunk. Az asszony ugyanis fokozott érzékenységet mutatott a veszély jelzései iránt, és arra törekedett - részben tudatosan, részben ösztönösen -, hogy a külső fenyegetettség és a belső bizonytalanságérzés megszüntetéséhez szükséges stratégiák, eljárások széles skáláját alkalmazza.

Viselkedéses föstratégiája a problémával való szembehelyezkedés, a konfrontáció volt, melynek jegyében számos egyéb stratégiát, eljárást használt. Többek között „elébe ment” az eseményeknek, felkészítette önmagát a kívülröl érkező támadásra. Veszélyérzetének engedve már 1929. június 18-án, tehát a deportálási döntés elött levelet írt a konzulnak, melyben nyílt kérést fogalmazott meg:

„Alul írott azon alázatos kérelemmel járulok Tekintesteséged [sic] elébe, hogy férjem Darab József Prince Alberti lakos jelenleg Batlefordon az Elme gyogy intézetbe van. [...] Méltoztason meg engedni és ki eszközölni hogy itt maradhason, hogy ne deportálják. [...] Méltoztason egy szerencsétlen asszony sorsát megkönyebíteni, hogy ne legyek kénytelen haza menni. Mert a férjem nélkül nem bírnék itt maradni., ${ }^{, 19}$

Vagyis az asszony arra kérte Schefbeck Jakab Istvánt, érje el, hogy férje választott hazájukban maradhasson, s így neki se kelljen repatriálnia.

Lényeges viselkedéses stratégiája volt a támogató, a szövetséges keresése (a konzul személyében) is, ezzel összefüggésben a meggyőző érvek felsorakoztatása. Ezek az érvek a történtekről kialakított saját olvasatából bontakoznak ki. Darab Józsefné már említett első, június 18-án írt levelében úgy emlékezett vissza, hogy férje május 4-én lett beteg, ekkor „,nagy hülése volt és nagy szék rekedése”. Mivel nem lett jobban, május 12-én orvost hívatott hozzá, aki orvosságot és pihenést írt elő a beteg számára, illetve azt tanácsolta az asszonynak, hogy amennyiben a férje nem tudna aludni, öriztesse, mert „rohamja lesz”. A férfi nem vette be az orvosságot, így „ki ütöt rajta a roham és meg szurt”. A feleség úgy vélte, a férje nem ép elmével követte el tettét, ezért nem állapítható meg a felelőssége. Továbbá

17 Boross Ottilia - Pléh Csaba (szerk.): Bevezetés a pszichológiába: olvasmányok és feladatok a lélektan alapkérdéseinek tanulmányozásához. Budapest: Osiris, 2004. 455.

18 A megküzdésnek több modellje, tipológiája is van. A legelterjedtebb felosztás szerint két nagy kategória különböztethető meg egymástól: a problémafókuszú és az érzelemfókuszú megküzdés. Egyesek ezen a duális felosztáson, vagy ennek kiegészített, újragondolt modelljén belül különítenek el további - viselkedéses és kognitív jellegü - megküzdési típusokat, eljárásokat. A megküzdés pszichológiájához 1. Boross - Pléh, 2004. 451-476. A saját elemzésemet nem illesztem a pszichológiai szakirodalomban található modellekbe, csak a viselkedéses és a kognitív megküzdési kategóriákat használom.

19 MNL OL K 139, 13. csomó, 1931, 1. tétel, 3222/D, 64-65. 
biztosította a konzult arról, hogy a férfi ,józan életü tisztességes és becsületes ember, aki törvénybe ütközö dolgot soh se cselekedet sem az Ó hazába sem itten az uj hazába". Emellett megosztotta félelmeit a deportálás lehetséges tragikus következményeiről. Szerinte deportálás esetén fennáll a veszélye annak, hogy a férje öngyilkos lesz, mert Magyarországon mindent eladtak, ott már „nincs mihez fogni”. Ezzel szemben Kanadában kilátásaik vannak az egzisztenciateremtésre (,[...] itt meg ha Isten segit, 3-4 év mulva ki mehesünk homstédra ${ }^{20}$ egy kis pénzel"), ráadásul már érzelmileg is kötödnek a helyhez (,,Mi meg szerettük eszt az országot aki be fogadot benünket és kenyeret adott."). Emellett kiemelte, hogy hajlandó a kórházi költségeket kifizetni, és hogy mindketten meg tudnak majd élni az ő varrónői keresetéből. Arról is tájékoztatta a konzult: esély van arra, hogy a férfi pár héten belül elhagyja a kórházat. ${ }^{21}$ Tehát az asszony azon az állásponton volt, hogy megérdemlik a kedvező elbírálást és a konzuli segítséget, mégpedig azért, mert a férje nem volt beszámítható tette elkövetésekor, ráadásul büntetlen elóéletü, képesek az önellátásra, érzelmileg kötődnek Kanadához, és a deportálás akár tragédiába is torkollhat. Érvelésével a tett súlyát kicsinyítette, és a deportálás lehetséges negatív következményeit hangsúlyozta. Darabné védekezése alapján feltételezhető, az asszony tisztában volt azzal, hogy a kanadai hatóságok nem tolerálják a beteg, elmezavarodott, büncselekményeket elkövető és közteherré váló bevándorlókat, és ellenük deportálási eljárást indíthatnak. Ezért érezhette szükségét annak, hogy azt bizonygassa, esetükben nem állnak fenn ezek a körülmények.

A szövetséges megnyerését célzó megküzdési stratégiához - az érvelésen kívül - egyéb eljárások is kapcsolódtak, mint az empátia, különböző érzelmek (sajnálat, együttérzés) kiváltása, és - férje megbízhatóságának szavatolásán, az anyagi erőfeszítés és a férje iránti felelősség vállalásának hajlandóságán keresztül - a bizalom kialakítása a konzulban.

Az egyik lehetséges olvasat szerint fent bemutatott első levele tárgyalási szituációra emlékeztet, ahol a hátrányos helyzetben lévő fél proaktív módon „elébe megy" az eseményeknek, feltárja a problémát, segítséget kér, a megoldását keresi; és saját pozíciója erősítését szövetséges megnyerésével, meggyőző érveléssel, érzelmek kiváltásával és anyagi erőfeszítés felajánlásával igyekszik elérni. Valószínübb azonban az, hogy a megküzdés folyamata korántsem volt ennyire átgondolt, tudatosan, hideg fejjel felépített, vagyis ezeknek a „stratégiáknak” egy részét a veszélyérzet mobilizálta a küzdeni képes, kitartó, céltudatos asszonyban, aki ösztönösen alkalmazott különböző, az érdekvédelem szolgálatába állítható eljárásokat. Lehetséges, hogy ezek a részben ösztönösen használt „technikák” olyan tudáselemek voltak, melyek a környezetükben lezajlott deportálási eljárások megfigyeléséből, más bevándorlók kitoloncolással szemben tett erőfeszítéseinek tapasztalatából

20 homestead $=$ telepes birtok

21 MNL OL K 139, 13. csomó, 1931, 1. tétel, 3222/D, 64-65. 
származtak. Továbbá azt is érdemes kiemelni, hogy az érzelmek kiváltására alkalmas kétségbeesett kérések, fordulatok vagy a bizakodó kijelentések ${ }^{22}$ mögött valódi félelmek, szorongások és remények léteztek.

A konzulnak az év második felében írt további leveleiben lényegében az említett cselekvéses erőfeszítéseket ismételte meg és egészítette ki. Nyílt kéréseket fogalmazott meg, és mindenekelött a konzul mint szövetséges megnyerésére fókuszált a korábban már felsorolt eszközökkel (érvelés, együttérzés kiváltása, bizalom kialakítása stb.). Ennek jegyében levelei egyikében (július 17.) hangsúlyozta saját szerencsétlenségét, a Kanadához való kötődésüket (,Meg szeretük ezt a kontrit ${ }^{23}$ ”), a deportálás kockázatát (inkább ö is meghal, mintsem „a nagy szegénységre” menjenek haza), és újból szavatolta férje megbízhatóságát („ő egy becsületes, jozan életü ember volt és semi törvénybe ütközö dolgot nem cselekedet"). ${ }^{24}$ Egy másik küldeményében (november 4.) azt emelte ki, hogy a kórházból a férfi gyógyultan tért haza (,a férjem egésséges munka képes”). ${ }^{25}$ Valamint megismételte, hogy kész a férje miatt anyagi kiadásokat vállalni, ha kell, ezt írásba is adja (augusztus 19.). ${ }^{26}$

A Darab Józsefné által írt levelekből a házaspárral történtek és a deportálási eljárás különböző elemei, epizódjai is kibonthatók, melyekre - a további megküzdési eljárások bemutatása előtt - érdemes röviden kitérni. Többek között kiderül, hogy az asszony félelmei megalapozottak voltak, a kanadai kormányzat a deportálásukra készült. Erre utalt az, hogy a bevándorlási hivatal képviselői, Thomas Gelley és két „inspector" július 12-én és 16-án kiszállt hozzájuk, és elvitték útlevelüket (férje ekkor még a kórházban volt). ${ }^{27}$ A levelekből (augusztus 19., október 17.) arra is fény derül, hogy az orvosi vizsgálatok a férfinél szifiliszt mutattak $\mathrm{ki}^{28}{ }^{28}$ ami deportálását is nagyban meghatározta; Darabné július 17-én egyébként még arról tájékoztatta

22 „Méltóztason egy szerencsétlen asszony sorsát meg könyebiteni”, „,Méltóztason el követni mindent, hogy egy szerencsétlen Magyar asszonyon segitsen”, ,Segitsenek egy szerencsétlen asszszonyon a jó Isten meg fizet Tekinteteségednek”, „Választ reménységgel várva”, ,[...] minden remény meg van rá hogy itt maradhasunk." stb. MNL OL K 139, 13. csomó, 1931, 1. tétel, 3222/D, 38., 51., 60., 65.

23 kontri/country $=$ ország

24 MNL OL K 139, 13. csomó, 1931, 1. tétel, 3222/D, 59.

25 MNL OL K 139, 13. csomó, 1931, 1. tétel, 3222/D, 38.

26 ,Hajlandó vagyok a férjemet 3 évig kezeltetni itt ebe az országba a saját költségemen, nem lesz az Álam terhére. Hisz itt már saját házam van és ado fizetője ezen Országnak. Válalom a felelöséget a férjemért s ha kell alá is irathatok az itteni Magyarokkal és az ismerös Angolokkal. [...] Még egyszer ismétlem, hogy nem fogok az Álam terhére lenni és férjemért válalom a felelöséget." MNL OL K 139, 13. csomó, 1931, 1. tétel, 3222/D, 50-51.

27 MNL OL K 139, 13. csomó, 1931, 1. tétel, 3222/D, 59.

28 „A fö orvos úr aszt felelte, hogy igen a fejével rendbe van egészen csak a vére cifiliszes [...]” MNL OL K 139, 13. csomó, 1931, 1. tétel, 3222/D, 50. Lásd még a konzul sorait: „,...] férje a bevándorlók meg nem engedett osztályába tartozik, tekintettel, hogy [...] syphilisben szenved." MNL OL K 139, 13. csomó, 1931, 1. tétel, 3222/D, 45. 
a konzult, hogy férjének „agytífusza” van. ${ }^{29} \mathrm{Az}$ asszony sorai azt is felfedik, hogy meggondolta magát, és úgy döntött, hogy amennyiben a férjét deportálnák, ő mégsem térne haza vele. Ezt egzisztenciális megfontolásokkal indokolta augusztus 22-i levelében:

„[...] én nem megyek vele haza. Nincs mihez fogni és így én itt dolgozhatom és öttet kezeltethetem. S ha ki tisztul a vére aszt hiszem orvosi bizonyitványal visza jöhet, ha nem akor anyit birok majd keresni, hogy egy mühejt nyithasson otthon. Talán egy pár év mulva én megyek haza, hogy öregségünkre legyen valami." ${ }^{30}$

A konzulnak küldött soraiból (november 4.) az is megtudható, hogy

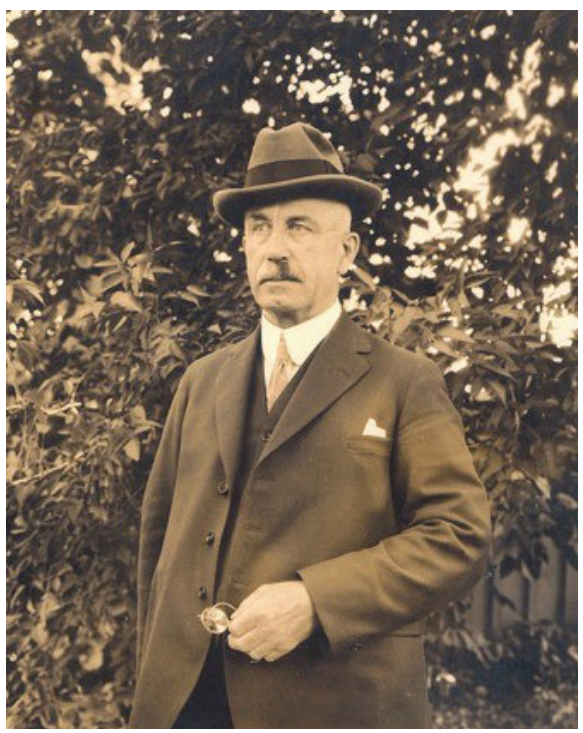

Thomas Gelley kanadai bevándorlási biztos 1930 körül férje valamikor szeptemberben, tehát hosszú hónapok után tért haza Prince Albert-i otthonába, ${ }^{31}$ és hogy Darabné megállapodott a hatóságokkal a férje utáni kórházi költségek részletekben történő kifizetéséről. ${ }^{32}$ Egy másik levele (november 7.) pedig azt teszi nyilvánvalóvá, hogy nem tudott angolul (alig egy-másfél éve volt Kanadában), ügyvédjével is tolmács útján érintkezett. ${ }^{33}$

A deportálási döntés után az asszony további megküzdési stratégiákat is alkalmazott. A szövetségesi kör bővítése jegyében egy ügyvédtől, Dr. Davistől is segítséget kért, ,hogy ha lehet az is segitsen” (augusztus 19.). ${ }^{34}$ Szintén lényeges, felértékelödött eljárásnak tekinthető a monitorozás, vagyis az információszerzés, ami a cselekvés-előkészítést és a csapásra való lelki felkészülést segítette elő. Egy kül-

29 MNL OL K 139, 13. csomó, 1931, 1. tétel, 3222/D, 59.

30 MNL OL K 139, 13. csomó, 1931, 1. tétel, 3222/D, 48.

31 MNL OL K 139, 13. csomó, 1931, 1. tétel, 3222/D, 37.

32 MNL OL K 139, 13. csomó, 1931, 1. tétel, 3222/D, 37.

33 „Tulajdon képen én nem is halotam [azt a megjegyzést, amit az ügyvéd a magyar konzulra tett - a szerz. megj.] de a tolmácsom mondta, mert még nem értem teljesen az angol nyelvet, így muszáj tólmácsot hívnom ha törvényesen akarok el intézni valamit.” MNL OL K 139, 13. csomó, 1931, 1. tétel, 3222/D, 34-35. Az angol nyelv ismerete nélkül érkező kanadai magyar bevándorlók nyelvhasználata, a hatóságokkal való érintkezésük gyakorlata egy következő kutatás tárgyát képezi.

34 MNL OL K 139, 13. csomó, 1931, 1. tétel, 3222/D, 37., 51. 
deményéböl (november 4.) kiderül, hogy Thomas Gelley winnipegi bevándorlási biztossal is felvette a kapcsolatot, aki megígérte neki, hogy amint a deportálási eljárással összefüggő hírt kap Ottawából, értesíti az asszonyt. ${ }^{35}$ Egy másik leveléböl (augusztus 19.) az is tudható, hogy amikor tájékoztatást kapott arról, hogy férjét gyógyíthatatlan betegség miatt akarják deportálni, azonnal felhívta az intézet főorvosát, „McNeel”-t, ${ }^{36}$ és megkérdezte, mi baja van a férfinak. Szifiliszes - tájékoztatta az orvos. ${ }^{37}$

A levelekből egy sajátos megküzdési eljárás, a félrevezetés, az elhallgatás is kitünik - ami a szövetséges keresésének stratégiájához kapcsolódott, és a konzulban kialakított bizalom elvesztésének megelőzését szolgálhatta. Ahogy már láttuk, a nő először azt írta a konzulnak, hogy férje agytífusztól szenved, majd arról tájékoztatta, hogy szifiliszes. A betegségröl azonban a feleség már korábban is tudhatott. Augusztus 19-i levelének egy részlete (,lehet, hogy soh se kapja visza, de lehet hogy visza kapja") ${ }^{38}$ ugyanis arra utal, hogy a férfi betegsége már a tünetmentesség, a lappangás szakaszában volt, ${ }^{39}$ és hogy a férjét már korábban is kezelték Kanadában szifilisszel. Ezt támasztja alá az, hogy amint hírt kapott arról, hogy a deportálási eljárás alapja a szifiliszes diagnózis, Darabné felkereste Dr. Reidet, azt az orvost, ,ki a férjemet elöször is kezelte”. Töle próbálta megtudni, hogy „,kitisztulna-e a vére", amennyiben a férje - továbbra is - kezelést kapna. Az orvos állítólag azt válaszolta, igen, de ehhez szüksége lesz három évre. ${ }^{40}$ Egy későbbi

35 MNL OL K 139, 13. csomó, 1931, 1. tétel, 3222/D, 37.

36 James MacNeill (1873-1945) a North Battleford-i elmegyógyintézet fóorvosa, egyben az intézmény egyik alapítója volt. Az orvos végzettségü MacNeill 1913-ban több hónapon keresztül tanulmányozta a pszichiátriát és a mentális betegek intézményi ellátásának módszertanát Angliában és az Amerikai Egyesült Államokban. 1914 és 1945 között volt az intézmény föorvosa, vezetője. Tevékenysége nagyban hozzájárult ahhoz, hogy a kórház a mentális betegségek kezelésének modern intézményévé vált. L. Mental Health Services. The Encyclopedia of Saskatchewan. https://esask.uregina.ca/entry/mental_health_services.jsp (Letöltés ideje: 2021. március 14.)

37 MNL OL K 139, 13. csomó, 1931, 1. tétel, 3222/D, 50.

38 MNL OL K 139, 13. csomó, 1931, 1. tétel, 3222/D, 50.

39 A szifilisz - ha nem kezelték megfelelően - több szakaszban zajlott le. Az első stádiumban, általában az első három hétben megjelentek a szifiliszes fekélyek, melyek néhány hét alatt spontán módon elmúltak. Hat héttel később, a második szakasz részeként változatos börtünetek és egyéb szimptómák (láz, fejfájás, nyirokcsomó-megnagyobbodás stb.) is jelentkeztek, ezek szintén elmúltak egy idő után. Ezt követően egy több éves időszak következett hosszabb tünetmentes periódusokkal. A kórokozó azonban idővel megtámadta a belső szerveket, és súlyos károkat, elváltozásokat okozott a szív- és érrendszerben, az idegrendszerben, a májban, valamint a bőrön és a csontokon is. Elég valószínü, hogy Darab József mentális zavarai összefüggésben álltak szifiliszével, mivel az kiváltója lehetett többféle neurológiai, pszichiátriai betegségnek is. A szifiliszhez és szövődményeihez 1. Tisza Tímea: Új trendek és kihívások a szexuális úton terjedő fertőzések területén. Magyar Tudomány, 2020/3. 333-335.

40 MNL OL K 139, 13. csomó, 1931, 1. tétel, 3222/D, 50. Ugyanebben a levélben az asszony azt állította, hogy Dr. McNeel sem ítélte a férjét gyógyíthatatlannak. 
küldeményében (november 4.) a nő azt állította a konzulnak, hogy férje „ezt a betegségét fluba kapta". ${ }^{41}$

Darabné soraiban néhány kognitív megküzdési technika is azonosítható. Az egyik annak a gondolatnak az interiorizálása volt, hogy nemcsak ők szerették meg Kanadát, de Kanada is megszerette öket (,szeretik az angol népek a munkámat s pártolnak"). ${ }^{42}$ A környezet befogadóként való érzékelése, a közeg szívélyességének tudatosítása valamelyest csökkenthette a nő belső feszültségét, és fokozhatta reményeit. Szintén a feszültséget mérsékelhette az önbiztatás és azon közlések felértékelése, melyek pozitív kimenetellel kecsegtettek: „Az ügyvédem még semit sem kapott Ottavából és biztat, hogy nem kel félnem [...]." ${ }^{\text {43 }}$

Szintén kognitív megküzdési eljárás volt a bünös azonosítása. Bár nem írta le leveleiben teljesen nyíltan, de bizalma megrendülhetett a konzulban. Ehhez hozzájárulhatott az is, hogy - ha hihetünk sorainak - ügyvédje Schefbecket vádolta a deportálási eljárás elindításáért, amit az asszony meg is írt a konzulnak november 4-i levelében. ${ }^{44}$ A bizalomvesztést mutatja, hogy ugyanebben „egyértelmüvé” akarta tenni, miért kérte a címzett segítségét:

„Én nem azért fordultam a M. K. Konzul Úrhoz, hogy haza deportáljon, hanem hogy meg voltam ijedve, hogy haza kell meni, és mi itt akarunk maradni, hogy segítsen a M. Úr rajtunk. ${ }^{, 45}$

A konzul másnapi levelében (november 5.) határozottan elutasította a vádakat, ${ }^{46}$ az asszony pedig utólag bocsánatot kért tőle (november 7.). ${ }^{47}$ Bár Darabné végig reménykedett a pozitív kimenetelben, leveleiben mind kétségbeesettebb hangot ütött meg.

$\overline{41}$ MNL OL K 139, 13. csomó, 1931, 1. tétel, 3222/D, 38. Valószínúleg azt szerette volna közölni, hogy férje nem ,hagyományos” úton, hanem valamiféle cseppfertőzéssel kapta el, ahogy az influenzát $(f l u)$ szokás.

42 MNL OL K 139, 13. csomó, 1931, 1. tétel, 3222/D, 60.

43 MNL OL K 139, 13. csomó, 1931, 1. tétel, 3222/D, 37.

44 Ebben Darab Józsefné azt írta, hogy az ügyvéd egészen elcsodálkozott a deportálási eljárás elinditásán, és azt mondta, hogy „Nem Magyar Konzul az, aki erővel deportál haza egy hozá segitségér fojamodo magyart". MNL OL K 139, 13. csomó, 1931, 1. tétel, 3222/D, 37.

45 MNL OL K 139, 13. csomó, 1931, 1. tétel, 3222/D, 38.

46 MNL OL K 139, 13. csomó, 1931, 1. tétel, 3222/D, 36.

47 „Nagyon szépen kérek bocsánatott ha meg sértetem a Méltóságos Urat. Én nem rágalmazom meg. Söt hálás vagyok érte, amit egy év múlva be is tudok bizonyitani egy gyönyörü abrosszal amit saját magam csinálom de köl egy év míg végzek vele. Biztos vagyok bene hogy a Méltóságos asszony nagyon fog örülni neki. [...] Távol áljon az tölem, hogy én kételkedjem szives fáradozásában.” MNL OL K 139, 13. csomó, 1931, 1. tétel, 3222/D, 34. 
A hatóságok november második hetében a winnipegi Bevándorlási Házba (Immigration Hall) internálták a házaspárt. ${ }^{48}$ Ez felkészületlenül, váratlanul érte őket, a ház eladása és 100 dollárnyi kintlévőségük összeszedése meg nem valósított feladatként tornyosult föléjük. ${ }^{49}$ November végén a nő elveszíthette a reményeit, mert 18-án már azt írta a konzulnak, hogy ha semmit sem lehet tenni, „,belenyugszunk a változhatatlanba". ${ }^{50}$

\section{A winnipegi magyar konzulátus látszószöge}

Az I. világháborút követően az önálló magyar külügyi szolgálat kiépítése hoszszabb folyamat volt. 1920 végéig tizennégy magyar követség, képviselet, konzulátus, konzuli képviselet kezdte meg munkáját, mind európai városokban (Bécs, Bern, Vatikán, Berlin, Hága, Róma, Varsó, Belgrád, Prága, Párizs, Berlin, Hamburg, Köln, Trieszt). 1921-ben Bukarestben, Stockholmban, Münchenben, Londonban, Szófiában és Washingtonban is létesült külképviselet, ugyanebben az évben a Nemzetek Szövetsége genfi központja mellé magyar titkárságot hoztak létre. 1922-ben Kolozsvárt útlevél-kirendeltség, Brüsszelben követség nyílt meg. 1922-ben tengerentúli városokban (New York, Chicago, Cleveland, Pittsburgh) is létrejöttek konzuli helyek. 1923-an Tallinnba és Milanóba, 1924-ben Isztambulba, 1925-ben Athénba és São Paulóba, 1926-ban Zárgrábba és Madridba, 1927ben Rio de Janeiróba és Pozsonyba, 1928-ban pedig Buenos Airesbe telepítettek magyar külképviseletet. Ami Kanadát illeti, 1922-ben Montrealban fökonzulátus, 1927-ben Winnipegben konzulátus nyílt, ${ }^{51}$ az első winnipegi konzul Schefbeck Jakab István ${ }^{52}$ lett. Konzuli joghatósága kiterjedt Manitoba, Saskatchewan, Alberta és British Columbia tartományaira, valamint Yukon területére és az Északnyugati

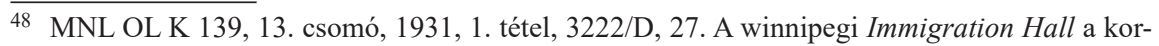
mányzat által, fóként az átvonuló bevándorlók részére fenntartott, és nagyjából 200 fő elhelyezésére alkalmas intézmény volt. (A montreali magyar konzul jelentése a Külügyminisztériumnak a nyugat-kanadai bevándorlás problémáiról és az ottani magyarok helyzetéről. In: Bán D. András - Diószegi László - Fejős Zoltán - Romsics Ignác - Vinnai Győző [szerk.]: Magyarok kisebbségben és szórványban. A Magyar Miniszterelnökség Nemzetiségi és Kisebbségi Osztályának válogatott iratai, 1919-1944. Budapest: Teleki László Alapítvány, 1995. 571.) Az Immigration Hall, akárcsak a többi kanadai intézmény magyar nyelvü említésekor a forrásokban szereplő magyar verziókat használom. Az Immigration Hall magyar megfelelöje a Bevándorlási Ház.

49 MNL OL K 139, 13. csomó, 1931, 1. tétel, 3222/D, 27.

50 MNL OL K 139, 13. csomó, 1931, 1. tétel, 3222/D, 20.

51 Pritz Pál: A bécsi követség története a két háború között. Külügyi Szemle, 2013/2. 61-62.

52 (Petényi) Schefbeck Jakab István (1884-1936) korábban a chicagói konzuli kirendeltség vezetője (konzuli címmel felruházott alkonzulja) volt. 1927 tavaszán helyezték a winnipegi konzulátus élére mint konzuli címmel felruházott alkonzult, 1928 augusztusában nevezték ki konzullá. A konzulátust haláláig vezette. 1934 januárjában Petényire változtatta a nevét. Külügyi 


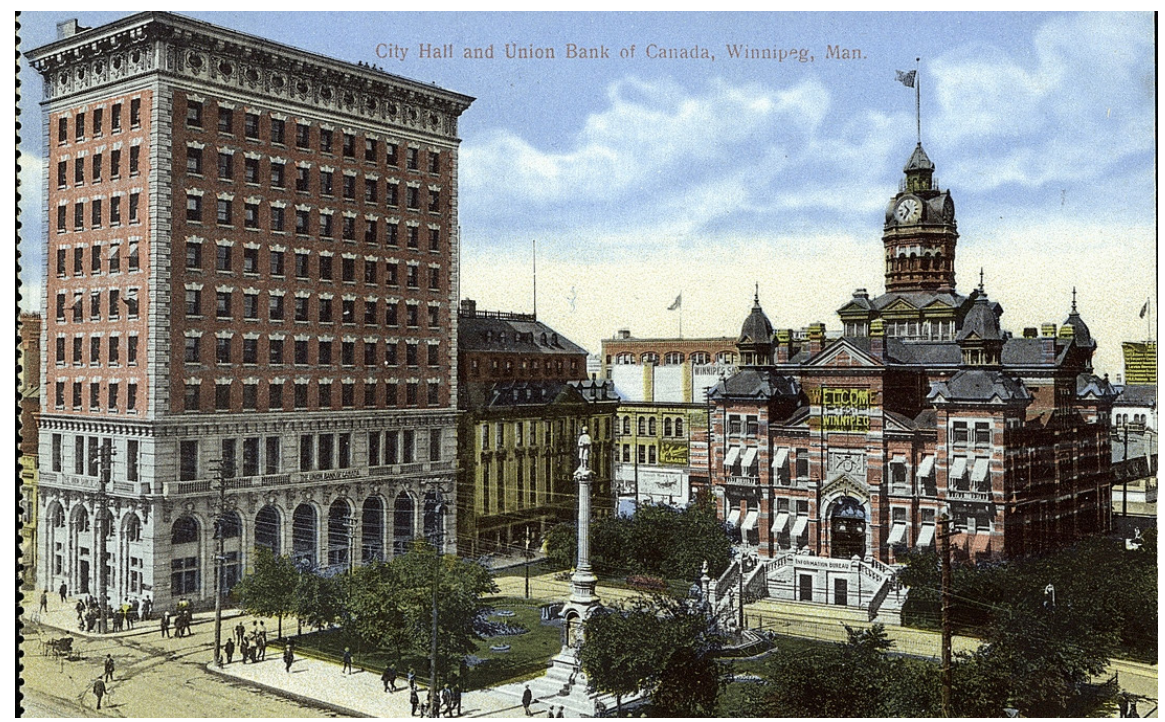

A magyar konzulátus helyszinéül szolgáló épület (Union Bank, később Royal Bank of Canada épülete) 1911-ben

régióra (vagyis Nyugat- és Észak-Kanadára). A winnipegi konzulátus 1927. május 26-án kezdte meg müködését. ${ }^{53}$

A winnipegi konzulátusi dokumentumok arról tanúskodnak, hogy a konzulnak elsősorban segítői-támogatói és hatósági (közjegyzői, útlevél-kiállítási, -megújítási stb.), valamint jelentéstételi feladatai voltak. A konzuloknak már a Monarchia korában is kötelességük volt az állampolgárok segítése, „oltalomban részesítése”. Ez az „oltalom” lehetett tanács, iránymutatás vagy különböző célokra (kórházi ápolás, temetkezés, hazautazás stb.) felhasználható pénzügyi gyorssegély, megelőlegezett költségtérítés. A konzuli feladatok közé tartozott a külföldi hatóságok előtt történő „,felszólalás”, az állampolgárok érdekképviselete is. ${ }^{54}$ A Monarchia korában és később is a konzulok a saját külföldi kerületükben gazdaságpolitikai szereppel is bírtak. ${ }^{55}$ Bár az 1920 utáni időszakból nem található a feladataikat és a tőlük elvárt magatartási normát részletesen elöíró jogszabály, a külügyi apparátus

Közlöny, 1922. június 20. 100., 1925. február 2. 31., 1927. május 30. 61.,1928. szeptember 15. 63., 1934. június 15. 31.

53 Külügyi Közlöny, 1927. július 15. 64.

54 Rényi József: A külügyi közigazgatás. Budapest: Franklin, 1912. 47-48.

55 Feladatuk volt közgazdasági jelentések írása is. Rényi, 1912, 46. Az 1918. évi V. néptörvény 6. § szerint: „A magyar konzuli hivatalok külföldi kerületükben föleg a hazai közgazdaság érdekeit szolgálják és ezen, valamint egyéb teendöket azon utasitások szerint látják el, amelyeket a magyar külügyminiszter vagy a felettes magyar diplomáciai képviselet útján nyernek." 
személyi állományának kiválasztási rendjéhez kapcsolódó 1920. évi 8.889 M. E. számú rendelet - mely a külügyi szolgálat fogalmazói szakában való alkalmazás feltételeit rögzítette - betekintést enged valamelyest a követelményekbe. A rendelet az apparátusba jelentkezőktől megkövetelte a megfelelő tanulmányokat, tapasztalatokat és a testi alkalmasságot, valamint a jogi, közigazgatási, gazdaságpolitikai, történelmi, földrajzi ismereteket és a nyelvi-fordítási kompetenciákat (utóbbiakat vizsgán kellett bizonyítaniuk). A jelölteknek a rendelet értelmében modor, fellépés, tapintat és a nemzeti gondolkodás tekintetében is meg kellett felelniük a külügyi szolgálat követelményeinek. ${ }^{56}$

Az alábbiakban a konzul „megküzdési”, ügykezelési stratégiáit vizsgálom, az előbbiektől eltérően nem az individuum és a magatartáspszichológia pozíciójából, hanem közigazgatási, külügyi tisztviselöi aspektusból. A kérdés tehát az, hogy a konzul hogyan, milyen cselekvési stratégiákkal kezelte a „Darab-ügyet”. Eljárása nemcsak az ügy részleteit, de a funkció megkövetelte segítő-támogatói és közvetítői szerepkört, általános magatartást, fellépést is elénk tárja. Schefbeck Jakab intézkedései döntően azt mutatják, hogy teljes mértékben megfelelt a konzulokkal szemben támasztott követelményeknek, a segítői szerepnek.

Schefbeck legfőbb ügykezelési stratégiája a lelkiismeretes támogatás, az együttmüködés volt. Ez magában foglalta a gyors válaszadást, az informatív tájékoztatást, valamint a dolgok megváltoztatására irányuló, levelezésen és személyes közbenjáráson alapuló intézkedést is. ${ }^{57}$

Példának okáért a Darab Józsefné által június 18-án írt és a konzulátuson 20-án iktatott aggódó levélre már 20-án válaszolt, ebben biztosította az asszonyt arról, hogy

,[...] ez a hivatal szívesen meg fog tenni mindent, ami törvények keretén belül megtehető, hogy férje ne deportáltassék, feltéve, hogy tényleg teljesen kigyógyul és hogy Ön képes lesz a kórházi költségeket kifizetni. [...] Ha férje deportálási [sic!] iránti intézkedés megérkezik ezen hivatalhoz, akkor újból fogok Önnek írni és meg fogjuk fellebbezni a deportálási rendeletet, de már most kell értesítenem arról, hogy ez a hivatal nem vállalhat felelösséget arra, hogy a bevándorlásügyi miniszter helyt is adjon ezen hivatal fellebbezésének."

A lényegre, az informativitásra fókuszáló leveleiben mindig világosan közölte Darab Józsefnével a kanadai bevándorlási hivatal hozzá eljuttatott döntéseit és várható lépéseit. Július 23-án például arról értesítette az asszonyt, hogy a bevándorlási hivatal azt követően fog dönteni a férje sorsáról, hogy egy bizottság megvizsgálta,

\footnotetext{
56 Magyarországi Rendeletek Tára 1920. Budapest: Magyar Kir. Belügyminisztérium, 1920. 527-534.

57 A személyes intézkedéshez lásd: MNL OL K 139, 13. csomó, 1931, 1. tétel, 3222/D, 58.

58 MNL OL K 139, 13. csomó, 1931, 1. tétel, 3222/D, 62.
} 
meggyógyult-e és keresőképes-e. ${ }^{59}$ Augusztus 15-én már arról tudósított - rögtön azután, hogy hírt kapott róla -, hogy a bizottság deportálásra ítélte a férfit. ${ }^{60} \mathrm{~A}$ saját kezdeményezéseiről, lépéseiről, a hatóságoknak írt levelei tartalmáról hasonló lelkiismeretességgel tájékoztatta a házaspárt.

A konzul tehát nemcsak tájékoztatott, de a dolgok menetét is megpróbálta megfordítani. Augusztus 26-án fellebbezést nyújtott be az ottawai bevándorlási biztosnak, amiben az asszonytól kapott információkat, érveket és saját argumentumait tolmácsolta a hivatalnak (Schefbeck azzal érvelt, hogy Magyarországra visszatérve a párnak rendkívül nehéz lesz eltartania magát). ${ }^{61}$ A fellebbezés azonban nem volt, nem is lehetett sikeres. A bevándorlási minisztérium arra hivatkozva, hogy a férfi eleve jogtalanul lépett Kanada területére, elutasította azt (október 12.). ${ }^{62}$

A konzul azonban nem adta fel, november 12-én - a winnipegi bevándorlási biztos, Thomas Gelley útján - kérelmet nyújtott be, amelyben arra kérte a kanadai hatóságokat, hogy függesszék fel a már a winnipegi Bevándorlási Házba internált házaspárral szemben foganatosított deportálási eljárást, legalább arra az időre, amíg Darabék eladják a javaikat, elintézik függő ügyeiket. De a legjobb az lenne, ha három évre elhalasztanák a végrehajtást. ${ }^{63}$ Schefbeck - ezzel a lépésével - hasznos, kiaknázható időt akart nyerni a párnak. Kérésével azonban csak az előbbit tudta elérni: Darabék november 30-i visszatérési kötelezettséggel elhagyhatták az Bevándorlási Házat, és néhány napra visszautazhattak Prince Albertbe. ${ }^{64}$ November 20-án a konzul újból benyújtotta felfüggesztési keresetét, amelyben azt kérte Thomas Gelleytől, hogy próbálja „,bevetni” a befolyását Ottawában, kérje a deportálás végrehajtásának legalább egy évre történő elhalasztását. ${ }^{65}$

Schefbeck képes volt félretenni sérelmeit is. Augusztus közepén értesült a deportálási döntésről, és arról, hogy az eljárás elindításának köze van a férfi betegségéhez. A fellebbezésre érkezett ottawai válaszból (október 17.) azt is megtudta, hogy Darab József szifiliszben szenved, és megbetegedése régi keletü. ${ }^{66}$ Talán benne is felmerült a gyanú, hogy a házaspár tudott a fertőzésről, csak elhallgatta előle ezt az információt. Ez azonban nem gátolta lelkiismeretes támogatói tevékenységében. Attól is eltekintett, hogy Darabék ügyvédje, Dr. Davis és maga Darab Józsefné is megsértette korábban a bizalmatlanságával (ki is kérte ezt magának egy levélben), és november 16-án levelet írt az ügyvédnek. Arra biztatta, hogy távirati

\footnotetext{
59 MNL OL K 139, 13. csomó, 1931, 1. tétel, 3222/D, 58.

60 MNL OL K 139, 13. csomó, 1931, 1. tétel, 3222/D, 54.

61 MNL OL K 139, 13. csomó, 1931, 1. tétel, 3222/D, 52-53.

62 MNL OL K 139, 13. csomó, 1931, 1. tétel, 3222/D, 45-46.

63 MNL OL K 139, 13. csomó, 1931, 1. tétel, 3222/D, 27-28. A felfüggesztés elérésére voltak példák a praxisában. MNL OL K 139, 1. csomó, 1928, 863. MNL OL K 139, 13. csomó, 1. tétel, 1931, 2394/D. MNL OL K 128 (Montreali Főkonzulátus), 2. csomó, 1932, I/2. tétel, 55., 57. stb.

64 MNL OL K 139, 13. csomó, 1931, 1. tétel, 3222/D, 20., 23.

65 MNL OL K 139, 13. csomó, 1931, 1. tétel, 3222/D, 18.

66 MNL OL K 139, 13. csomó, 1931, 1. tétel, 3222/D, 45., 54.
} 
úton kérje ő is a végrehajtás felfüggesztését, és vállaljon kezességet a házaspárért. Szerinte mindezek, valamint a közös „offenzíva”, az együttes erőfeszítések (combined efforts) eredményre vezethetnek. ${ }^{67}$

A konzul a közvetlen egyeztetésekre is figyelmet fordított: személyesen is meghallgatta a Bevándorlási Házba internált házaspár panaszait, és a felfüggesztésre vonatkozó november 12-i kérelmét személyesen adta át Thomas Gelleynek. ${ }^{68}$ November 29-én Gelley arról tájékoztatta öt, hogy a minisztérium elutasította legutolsó halasztási kérelmét is ${ }^{69}$ ami azt jelentette, hogy minden reménye elszállt Darabéknak a maradásra. A konzul a házaspár érdekeinek védelme közben természetesen együttmüködött a kanadai hatóságokkal, például kérésükre meghosszabbította a házaspár útleveleit (1930. február 28-ig), alkalmassá téve őket a hazatérésre. ${ }^{70}$

\section{A kanadai bevándorlási hatóságok látószöge}

A deportálás, de maga a bevándorlás is különböző hatóságok ügykörébe tartozott. 1892-ben a földművelésügyi minisztériumtól (Department of Agriculture) a belügyminisztériumhoz (Department of the Interior) került át, amelynek keretén belül 1893-ban létrehoztak egy külön, a bevándorlással és a deportálással foglalkozó osztályt (Immigration Branch). 1917-ben megalakítottak egy külön bevándorlási és kolonizációs minisztériumot (Department of Immigration and Colonization), mely ebben a formában 1936-ig müködött. ${ }^{71}$ A deportálás jogi alapját és eljárásrendjét az 1906., majd az 1910. évi bevándorlási törvények (Immigration Act) rögzítették.

Az 1910. évi törvény a deportálást a Kanadába érkezett vagy a Kanadában lévő bevándorlók vagy más személyek eltávolításaként (removal) definiálta. ${ }^{72}$ A törvény szerint az országba nem léphetnek be a „tiltott osztályokba” (prohibited classes) tartozók, bizonyos speciális helyzetektől eltekintve. Ide tartoznak - többek között - az elmebetegek, az epilepsziások, az utálatos (loathsome) és fertöző betegségben (contagious or infectious disease) szenvedők; a némák, a vakok

67 MNL OL K 139, 13. csomó, 1931, 1. tétel, 3222/D, 23.

68 MNL OL K 139, 13. csomó, 1931, 1. tétel, 3222/D, 27.

69 MNL OL K 139, 13. csomó, 1931, 1. tétel, 3222/D, 10.

70 MNL OL K 139, 13. csomó, 1931, 1. tétel, 3222/D, 41., 43.

71 Roberts, Barbara: Whence They Came: Deportation from Canada 1900-1935. Ottawa: University of Ottawa Press, 1988. 2. A bevándorlással foglalkozó minisztérium a magyar nyelvü konzulátusi iratokban rendszerint két néven - mint bevándorlási és bevándorlásügyi minisztérium - fordul elö.

$72,,[. .$.$] removal under authority of this Act of any rejected immigrant or other person, or of any im-$ migrant or other person who has already been landed in Canada [...] to the place whence he came to Canada, or to the country of his birth or citizenship." Immigration Act, 1910. https://pier21.ca/ research/immigration-history/immigration-act-1910 (Letöltés ideje: 2021. március 14.) 
és a mozgássérültek. ${ }^{73} \mathrm{~A}$ törvény szerint a bevándorlókat, mielőtt partra lépnének Kanadában, mentális és fizikai vizsgálatnak vetik alá. A már Kanadában lévő személyek köréből deportálható az, aki - nem kanadai állampolgárként - három éven belül elkövet egy büncselekményt, prostituálttá válik, koldus vagy közteher (public charge) lesz, börtönbe, kórházba, elmegyógyintézetbe (insane asylum) kerül, vagy az, aki a jelen törvény rendelkezéseivel ellentétesen lépett Kanada területére. A helyi hatóságok feladata, hogy értesítsék a bevándorlási hivatalt vagy a minisztert a fenti kategóriákhoz, a nem kívánt osztályokba tartozó bevándorlókról. A panasz nyomán a miniszter elrendelheti a vizsgálatot a vizsgálóbizottságok (Board of Inquiry) és a bevándorlási tisztviselő (officer) útján. Ha bebizonyosodik, hogy a bevándorló a tiltott osztályokhoz tartozik, haladéktalanul deportálandó. A bevándorlók belépéséről és deportálásáról szóló miniszteri, vizsgálóbizottsági határozatok nem fellebbezhetők meg a bíróságon. A deportálásra ítélt személy fellebbezésével a miniszterhez fordulhat. Ha elrendelik a családfő deportálását, minden tőle függő családtagot is deportálni kell. Ha egy függő családtagot ítélnek deportálásra, mert közteherré vált, és bebizonyosodik, hogy ez a családfő vagy a családtagok hanyagságának következménye, akkor a családfő és a családtagok is deportálandók. Az ilyen deportálás költségei az érintetteket terhelik, ha nincs pénzük, a kanadai állam fizeti. ${ }^{74} \mathrm{Az}$ öt évnél régebben Kanadában lévő bevándorlókat csak büncselekmény elkövetése miatt lehetett deportálni. ${ }^{75}$

A deportálás - a téma egyik ismerője szerint - valójában olyan intézmény volt, mely a munkaadókat, az önkormányzatokat és az államot tehermentesítette, és mely egy, a bevándorlókat eltávolítható vendégmunkásokként kezelő bevándorlópolitikához kapcsolódott. Ez azt jelenti, hogy bár Kanada a letelepedést, a kanadaivá válást szorgalmazta, nem vállalt teljes körü felelösséget a bevándorlókért: ha az országba érkezők kudarcot vallottak az önfenntartást biztosító eredményes munkavégzés terén, és közteherré (public charge) váltak, a hatóságok egyszerúen eltávolították őket Kanadából. A deportálást lényegében eszközként lehetett használni az olcsó munkaerő iránti, a konjunkturális időszakokra jellemző kereslet és a dekonjunktúra periódusaiban jelentkező munkaerő-túlkínálat közti egyensúly fenntartására, vagyis a profit maximalizálására és a veszteség minimalizálására. A bevándorlók védelmét, a munkaerőnek az országban tartásáért tett erőfeszítéseket szükségtelenné tette a kanadai kivándorlás

73 Szintén a tiltottak csoportjához sorolandók azok, akiket korábban büncselekmény miatt ítéltek el, valamint a prostituáltak, a hivatásos koldusok és a csavargók. Immigration Act, 1910. https://pier21.ca/research/immigration-history/immigration-act-1910 (Letöltés ideje: 2021. március 14.)

74 Az 1910. évi törvény deportálással kapcsolatos rendelkezései föként a 40-48 számú cikkelyekben találhatók. Az 1910. évi bevándorlási törvény szövege elérhető itt: https://pier21.ca/ research/immigration-history/immigration-act-1910 (Letöltés ideje: 2021. március 14.)

75 MNL OL K 139, 13. csomó, 1931, 1. tétel, 2698. A konzul levele Zajácz Andrásnak és Borbé Pálnak. 
iránti széles körü „érdeklődés”, a bevándorlás addig tapasztalt üteme. ${ }^{76} \mathrm{~A}$ konzuli iratok alapján azonban mégis feltételezhető, hogy a deportálási eljárás elindításának jogával felruházott hatóságok sok esetben nem éltek a lehetőséggel. A winnipegi magyar konzul szerint „A jelenlegi nehéz gazdasági helyzetre való tekintettel azonban a kanadai bevándorlási minisztérium azoknak a deportálási ügyét, akik saját hibájukon kivül estek a köz terhére, elnézöen kezeli". ${ }^{77}$

A deportálások száma valójában az 1920-as évek végén kibontakozó gazdasági világválság és következményei, mindenekelött a munkanélküliség miatt ugrott meg, ebben az időszakban ugyanis egyre több bevándorló került siralmas élethelyzetbe, és szorult segélyre. Az ily módon közteherré váló személyek ellen a városi hatóságok bejelentései nyomán a bevándorlási minisztérium vizsgálatot indított, majd kezdeményezte deportálásukat. A kiutasítások száma 1930 előtt nem haladta meg az évi 2000-et, 1929-ben még „csak” 1964 esetben került sor erre. 1930-ban és különösen 1931-ben azonban jelentős mértékben megemelkedett a deportálások száma, mely 1933-ban érte el tetöpontját (1930-ban 3963, 1931-ben 4376, 1932ben 7025, 1933-ban 7131 esetben intézkedtek). ${ }^{78}$ Nehéz megállapítani a deportálásoknak a kiutasítási ok szerinti megoszlását, mivel előfordult, hogy a döntést több mindennel indokolták a hatóságok. ${ }^{79}$ A minisztérium saját statisztikái szerint 1929ben leginkább egészségügyi okok (medical cause) miatt rendelték el a deportálást (650 esetben), 1930-ban már a közteherré válás vált elsődleges indokká (2106 esetet soroltak ebbe a kategóriába). ${ }^{80}$ Ami a magyar emigránsokat illeti, a válság előtt évente körülbelül két tucat magyar bevándorlót deportáltak Kanadából. 1930-ban ez a szám megugrott (31 fö), 1931-ben növekedett (121 fö), és 1932-ben érte el csúcspontját (170 fö). 1934-re a szám visszatért az 1929 elötti szintre. ${ }^{81}$ Egy, a winnipegi konzulátusi iratok között fennmaradt kimutatás - mely vélhetőleg csak az

76 Roberts, 1988. 5-9.

77 MNL OL K 139, 13. csomó, 1931, 1. tétel, 3288. Levél a konzultól Hangó Pálnak. Egy másik helyen hasonló megállapítást tett: „A mai kivételesen rossz gazdasági viszonyok között azonban a deportálási itélet végrehajtása elött a kanadai hatóságok csak akkor deportálják a köz terhére esö embereket az eddigi tapasztalatok szerint, ha az nem tud semmiképen sem munkát találni és családjáról gondoskodni saját erejéből." MNL OL K 139, 13. csomó, 1931, 1. tétel, 2802. A konzul levele Schmidt Mátyásnak.

78 Roberts, 1988. 38. Ezzel a folyamattal egy időben csökkent a bevándorlók száma, az 1932-ben bevándorolt népesség az 1930-ban érkezettek számának mindössze 16\%-át tette ki. L. Roberts, 1988. 38 .

79 Roberts, 1988. 105-106.

80 Roberts, 1988. 44. Ugyanakkor fontos megjegyezni, hogy az egészségügyi okoknál fogva kiutasítottak (balesetet szenvedett munkaképtelenek, tüdőbajosok, szívbetegséggel, epilepsziával, pszichés problémákkal küzdők stb.) rendszerint képtelenek voltak az önfenntartásra. Vagyis helyzetük nagyon hasonlatos volt azokéhoz, akik közteherré váltak. A betegek egy részét mint közteherré váló személyeket deportálták. L. Roberts, 1988. 105-106. 133.

81 Dreisziger F. Nándor: Immigrant Lives and Lifestyles in Canada, 1924-1939. Hungarian Studies Review, No. 1. Spring/1981, 76-77.; Dreisziger F. Nándor: A Decade of Setbacks: The 
adott körzetre vonatkozott - szerint 1932 első félévében 47 magyart deportáltak, többségüket, 31 föt saját kérelmére, 9 föt közteherré válás, 3 főt bủncselekmény, 2 főt elmebetegség, 2 főt pedig nemi betegség miatt. 1929-böl egyelöre nem rendelkezem hasonló adatokkal. Az 1932. évi kimutatás mindenesetre a gazdasági válságnak a magyar népességet érintő súlyos következményeit tükrözi vissza, ugyanis a „saját kérelmükre” deportáltak rendszerint az éhezés, a nincstelenség kínzó viszonyaiból kerestek kiutat akkor, amikor maguk kezdeményezték a kanadai állam által finanszírozott deportálásukat. ${ }^{82}$ A gazdasági válság időszakában hazatérők másik csoportját azok alkották, akik saját költségükön vagy megelőlegezett összegekből kedvezményes vagy ingyenes vasúti és hajójegyeket szerezve repatriáltak Magyarországra, szintén önkéntes alapon. ${ }^{83}$

Ha a kanadai bevándorlási hatóságoknak a Darab házaspár esetében alkalmazott „megküzdési” stratégiáit, ügykezelését nézzük, akkor világos, hogy azokat teljes mértékben a bevándorlási törvény által elöírt eljárásrendhez igazították, vagyis a jogszabályoknak megfelelően jártak el. Az ez ügyben kezdeményezett eljárásnak - kanadai oldalról - négy szereplöje volt: az ottawai bevándorlási minisztérium, a házaspár ügyét kivizsgáló bizottság, a konzulnak küldött leveleket a minisztérium képviseletében aláŕró A. L. Jolliffe, valamint a bevándorlási minisztérium - már említett - regionális képviselője, a winnipegi bevándorlási biztos (division commissioner of immigration), Thomas Gelley. ${ }^{84} \mathrm{~A}$ Thomas Gelleyvel való kapcsolatfelvételt két dolog tette szükségessé: egyfelöl a házaspárnak a deportálási határozatot követő winnipegi internálása, ami miatt a felmerülő ügyekben

1930's. In: Dreisziger F. Nándor (ed.): Struggle and Hope. The Hungarian-Canadian Experience. Toronto: McClelland \& Stewart, 1982. 141-142.

82 L. ehhez például: MNL OL K 139, 13. csomó, 1931, 1. tétel, 3150. Jelentés Valykó Mihály kérésérool. MNL OL K 139, 1. csomó, 1928, 1. tétel, 580. Lutz Ádám levele a konzulnak stb. Mások viszont mindenképpen el akarták kerülni a kiutasítást. Egyesek azért, mert úgy vélték, hogy a deportálás szégyenteljes dolog. Irtóztak attól, hogy pénz nélkül, lerongyolódva menjenek haza. MNL OL K 139, 13. csomó, 1931, 1. tétel, 2781/D. Kajári István levele a konzulnak.

83 1932-ben 743 ember tért haza Kanadából, ebből a deportáltak száma 170 fő volt. L. Dreisziger, 1981, 83. Egy önkéntes hazatérési esetet mutat be: Kulcsár Beáta: Adaptációs kísérletek Kanadában. Egy magyar emigráns küzdelmei az 1920-as évek második felében. Pro Minoritate, 2021/1. 3-18.

84 Thomas Gelley (1860-1939) farmer, könyvelö, politikus, bevándorlási biztos. Quebecben született. A Levis Commercial College-ben tanult. 1882-ben érkezett Manitobába, ahol gazdálkodott, majd Winnipegben könyvelöként dolgozott. 1886-1892 között a manitobai törvényhozó testületben (Legislative Assembly of Manitoba) Cartier körzetet képviselte. A politikai pálya elhagyását követően, 1899-1931 között a bevándorlási minisztérium tisztviselője, bevándorlási biztosa volt. L. Robertson, J. P.: Political Manual of the Province of Manitoba and the North-West Territories. Winnipeg: Call Print. Co., 1887. 61. Winnipeg Free Press, 13 March 1939, 4. 
őt kellett keresni; ${ }^{85}$ másfelől mivel a konzul jó viszonyt ápolt Thomas Gelleyvel, ${ }^{86}$ arra számított, hogy a közvetítésével elérhető a deportálás elhalasztása Ottawában.

A levelekből feltételezhető, hogy a férfi elmegyógyintézetbe kerüléséröl a törvényeknek megfelelően - a kórház értesítette az ottawai bevándorlási minisztériumot, amely ezt követően egy bizottságra bízta Darab József helyzetének kivizsgálását. ${ }^{87}$ A minisztérium képviseletében kommunikáló A. L. Jolliffe 1929. augusztus 6-án levelet küldött Schefbecknek, melyben leírta azt, amit a házaspárról kiderítettek, és a levélhez Darab József és Józsefné útleveleit is csatolta. A konzullal való kontaktus felvételének elsődleges oka az volt, hogy még a deportálásról szóló döntés előtt el akarta érni nála az útlevelek meghosszabbítását vagy új útlevelek kibocsátását, ${ }^{88}$ vagyis a deportáláshoz, a hazatéréshez szükséges feltételek kialakítását. Legközelebb (augusztus 15.) már a férfi ellen hozott deportálási határozatról küldött értesítő levelet a konzulnak. ${ }^{89} \mathrm{~A}$ nő kiutasításáról szóló határozat megszületésének időpontja nem ismert. Kérdés azonban, hogy miért deportálták a házaspárt, mire alapozta döntését a minisztérium? A válasz elsősorban a férfi deportálásáról szóló határozatot megfellebbező konzuli beadványra adott minisztériumi válaszból olvasható ki.

A feleségét megtámadó férfi nem volt bünöző: nem született ellene jogerős bírósági ítélet, vélhetőleg feljelentésre sem került sor, továbbá köztehernek sem minősült, ezek tehát nem jöhettek számításba mint indokok. Betegségei viszont kiszolgáltatottá tették, a bevándorlási törvény ugyanis lehetőséget biztosított arra, hogy elmezavara, elmegyógyintézeti internálása, szifilisze miatt deportálják. Döntőnek azonban a Kanadába való belépés körülményei bizonyultak. Az A. L. Jolliffe által aláírt levélből (október 12.) kiderül, hogy a hatóságok a nyomozás során megállapították, hogy Kanadába érkezése idején Darab József nem volt földmüves, ahogy azt állította. Cipész volt, ez volt a foglalkozása Magyarországon is. Szintén lényeges tényezőnek bizonyult, hogy súlyos szifilisze a vizsgálatok szerint régi eredetü volt, vagyis már fertőzöttként érkezett Kanadába. ${ }^{90}$ Márpedig a kanadai bevándorlási törvények egyfelől csak a gazdálkodók, földművesek és háztartási alkalmazottak befogadását tették lehetővé, ${ }^{91}$ másfelől - ahogy azt láttuk - a fertőző betegséggel érkezőket a tiltott csoportok osztályába sorolták. Vagyis a fő gond az

85 MNL OL K 139, 13. csomó, 1931, 1. tétel, 3222/D, 27.

86 A jó viszonyra a konzulátusi ügyintézésböl, a Schefbeck és a Gelley közti gyakori levélváltásokból, azok hangvételéből lehet következtetni. Thomas Gelley magyar közösségi eseményekre is meghívást kapott. 1924-ben a winnipegi Jézus szíve római katolikus hitközség alakuló gyülésére hívták meg, ahova el is ment. L. Ruzsa, 1940. 60.

87 MNL OL K 139, 13. csomó, 1931, 1. tétel, 3222/D, 55.

88 MNL OL K 139, 13. csomó, 1931, 1. tétel, 3222/D, 55-56.

89 MNL OL K 139, 13. csomó, 1931, 1. tétel, 3222/D, 54.

90 MNL OL K 139, 13. csomó, 1931, 1. tétel, 3222/D, 46.

91 Kanadába utazók részére szükséges tudnivalók és felvilágositások. Budapest: Cunard Line, [1924] 4. 
volt, hogy Darab József betegsége és foglalkozása révén már bevándorlása idején is nemkívánatos személynek minősült, be sem léphetett volna Kanada területére. Súlyosbító körülmény lehetett, hogy a férfi - azáltal, hogy magát földmüvesnek és egészségesnek tüntette fel - félrevezette a hatóságokat. A bevándorlási minisztériumnak tehát könnyü dolga volt: Kanadába érkezésének körülményei és kanadai betegeskedése egyaránt lehetővé tették Darab József deportálását; ráadásul a törvény úgy rendelkezett: ha bebizonyosodik, hogy a bevándorló a tiltott osztályokhoz tartozik, haladéktalanul deportálandó. Nincs arra utaló jel, hogy Schefbeck magyar konzul gyanakodott volna, ő az elején vélhetőleg azt hitte, hogy a hatóságok Kanadában kiütköző egészségi gondjai miatt akarják kiutasítani a férfit.

A vonatkozó dokumentumok hiányában jóval nehezebb kitalálni, hogy miért jutott a férjééhez hasonló sorsra a stabil egzisztenciával rendelkezö, egészségesnek tủnő asszony. Az iratokból annyi mindenképpen kiderül, hogy ő is a figyelem középpontjába került, és az ő egészségi állapotát is vizsgálták. ${ }^{92}$ Valószínüsíthető, hogy a kanadai hatóságok úgy ítélték: varrónő lévén ő sem kapcsolódik a földmüvességhez, és férjétől még megérkezése elött elkaphatta a betegséget; továbbá ő is félrevezette a hatóságokat - mindezek miatt pedig nemkívánatos személy és deportálandó. A nő számára kedvezőtlen döntést a férj fellebbezésére érkezett válasz is elörevetítette, ez ugyanis úgy fogalmazott, hogy ,a férjet és a feleséget nem lett volna szabad beengedni ebbe az országba." A hivatal úgy ítélte meg, hogy „semmiféle indok nincs arra, hogy megengedjék nekik a Kanadában maradást”.93

Vagyis Darab Józsefné hiába védekezett azzal, hogy férje nem bünöző, betegségéből kikezelhető, és hogy egyikük sem lesz közteher. Bár nem volt teljesen érdektelen a hatóságok számára az, ami Kanadában történt a házaspárral, ök elsősorban arra a kérdésre fókuszáltak, hogy mit tettek a múltban, milyen körülmények között léptek be az országba. A történtek azt is jól láttatják, hogy a bevándorlás biztonságos rendjén ,rések” voltak. Darab József a Cunard Line hajózási társaság által müködtetett Lancastria nevü óceánjáró hajón érkezett Kanadába. A Cunard társaság előírta, hogy az általuk szállított utasok már a budapesti irodában orvosi vizsgálaton essenek át, ${ }^{94}$ a partraszállás elött pedig az állam képviseletében eljáró orvosok is megvizsgálták őket. Ennek ellenére sehol nem észlelték a férfi betegségét.

Az eljárás tehát a törvényeknek megfelelően zajlott le, az egyetlen dilemmát okozó elem a férfi és a nő foglalkozása maradt. A vizsgálódó ottawai hatóságok ugyanis azt állították, hogy a férfi már Magyarországon is cipész volt, és Kanadában

92 „Information is not yet available as to wheather Mrs. Darab has also contracted veneral disease but investigation in this regard is being made." MNL OL K 139, 13. csomó, 1931, 1. tétel, 3222/D, 46.

93 ,[...] he and his wife would not have been permitted entry to this country and [...] there is not justification for permitting them to remain in Canada." MNL OL K 139, 13. csomó, 1931, 1. tétel, 3222/D, 46.

94 Kanadába utazók részére szükséges tudnivalók és felvilágositások, 1924, 13-14. 
is döntően ezt a tevékenységet folytatta. ${ }^{95} \mathrm{Az}$ asszony pedig - ahogy azt láttuk varrónő volt. Az útlevelek megújítása során kitöltött konzulátusi nyomtatványok szerint azonban a magyar hatóságok által kiállított útleveleikben az szerepelt, hogy földmüvesek. ${ }^{96}$ November 7-i levelében a nő azt állította, hogy férje nem hivatásos cipész, otthon is gazdálkodott. ${ }^{97}$ Ugyanakkor leleplező erejü az a konzulnak küldött levél, amelyben Darabné azzal érvelt deportálása ellen, hogy maradása esetén anyagilag támogatná otthon élő férjét, elősegítené azt, hogy mühelyt nyisson Magyarországon. ${ }^{98}$ Ha valóban igazuk volt a kanadai hatóságoknak, feltételezhető, hogy a Zemplén vármegyei alispáni hivatal olykor a kivándorlók igényeinek megfelelően töltötte ki az útleveleknek a foglalkozásra vonatkozó rubrikáját.

A történtekből az is látható, hogy a deportálási eljárás végrehajtásának folyamatában az ügyintézés átkerült a helyi „divízióhoz”, a winnipegi bevándorlási biztoshoz, ezért a konzul rajta keresztül érintkezett Ottawával. Továbbá az a következtetés is megfogalmazható, hogy a deportálási eljárás viszonylag hosszú folyamat volt, Darabék esetében bö fél évet vett igénybe: a férfi ügyének kivizsgálása és a döntéshozatal három hónapba telt, a többi a deportálás előkészítésére és végrehajtására kellett. A több hónapos időintervallumot a magyar bevándorlók közül azok, akik rossz körülmények között tengődtek, és mindenképpen haza akartak térni, nagyon hosszúnak élték meg. ${ }^{99}$

A Winnipegre, a Bevándorlási Házba november végén visszatérő Darab Józsefet és Darab Józsefnét végül december 2-án indították el Montreal, tehát a kikötő irányába. Utolsó előtti levelében, melyet már a vonaton írt, az asszony bocsánatot kért a konzultól amiatt, hogy nem búcsúztak el személyesen, egyúttal köszönetet mondott az erőfeszítésekért:

„Igy most levélbe kérünk bocsánatott és köszönjük szépen a Méltóságos úr fáradozását. A vonat ráz és nem tudok szebben írni. A jó Isten áldja meg a méltóságos urat. Maradunk mély tisztelettel, Darabné és férje."100

95 MNL OL K 139, 13. csomó, 1931, 1. tétel, 3222/D, 46.

96 MNL OL K 139, 13. csomó, 1931, 1. tétel, 3222/D, 40., 42.

97 MNL OL K 139, 13. csomó, 1931, 1. tétel, 3222/D, 35.

98 MNL OL K 139, 13. csomó, 1931, 1. tétel, 3222/D, 48.

99 A beteg Gerster János arra panaszkodott, hogy a deportálási eljárás túl hosszúra nyúlik, azt kérte a konzultól, próbálja meg felgyorsítani a folyamatot. MNL OL K 139, 13. csomó, 1. tétel, 1931, 3273.

${ }^{100}$ MNL OL K 139, 13. csomó, 1931, 1. tétel, 3222/D, 7-8. 


\section{Összefoglalás}

A messzi kanadai préri egyik városában és a deportálás fenyegetésében élő magyar házaspár, mindenekelőtt Darab Józsefné elszántan reprezentálta saját érdekeit, ennek részeként számos viselkedéses és kognitív megküzdési stratégiát, eljárást „,bevetett" a kiutasítás elkerülésére és a belső feszültségek, a szorongás csökkentésére. Ezek közé tartozott a nyílt kérés, a szövetséges keresése, az érvelés, az együttérzés kiváltására való törekvés, az anyagi erőfeszítések vállalása, a jó szándék szavatolása, a monitorozás, az elhallgatás vagy az önbiztatás; továbbá annak a gondolatnak az interiorizálása, hogy nemcsak ők kötődnek Kanadához, de Kanada, ,, $a z$ angol népek" is ragaszkodnak hozzájuk. Védekezési mechanizmusainak egy része - férje földmüves foglalkozásának, javuló egészségének hangsúlyozása, bünöző mivoltának tagadása és önfenntartásra való alkalmasságuk kiemelése stb. - jelzi, hogy tisztában volt a deportálás rendjével, azzal, hogy rendszerint milyen körülményekre hivatkoztak a hatóságok a deportálási határozatokban. A cselekvéses megküzdési stratégiáknak a kognitív eljárásokkal szembeni túlsúlya, számos belső kontrollmechanizmus (a probléma tagadása, ezáltal a cselekvés elutasítása, a bünbakkeresés stb.) hiánya mutatja, hogy az asszony megváltoztathatónak érzékelte a fenyegető külső viszonyokat, bízott abban, hogy aktív hozzáállással elkerülhetik a legrosszabbat. A megküzdés folyamatát azonban nem érdemes egy minden részletében végiggondolt, hideg fejjel felépített cselekvési programként elgondolni. Valószínübb, hogy a „stratégiák” jó részét a veszélyérzet mobilizálta a küzdeni képes asszonyban, aki ösztönösen alkalmazott különböző, az érdekvédelem szolgálatába állítható technikákat. Az érzelmek, az együttérzés kiváltására alkalmas kétségbeesett kérések és a bizakodó kijelentések mögött pedig valódi félelmek, szorongások és remények léteztek. Küzdelme az „Óhazától” elszakadt magyar bevándorlók adaptációs kihívásokkal és gondokkal teli életének epizódjait eleveníti fel. Az asszony erőfeszítései azonban nem bizonyultak hatásosaknak.

A winnipegi magyar konzul, Schefbeck Jakab István ügykezelési cselekvési stratégiái a segítőkész hozzáálláshoz kapcsolódó eljárások voltak: gyors válaszadás, informatív tájékoztatás, a dolgok megváltoztatására irányuló törekvések, benyújtott fellebbezéseken, halasztási kérelmeken, személyes ügyintézésen keresztül megvalósított szakadatlan erőfeszítések. Mondhatni, ,szövetségesévé” tudott válni a deportálásra ítélt magyar házaspárnak, ami találkozott ezek elvárásaival. Azonban, ha beássuk magunkat a konzulátus fennmaradt iratgyüjteményébe, nyilvánvalóvá válik, hogy a konzul segítő aktivitása független volt Darab Józsefné erőfeszítéseitől, és inkább egy, a konzul által interiorizált cselekvési normához kapcsolódott, melynek középpontjában a magyar állampolgárok problémái iránti érzékenység és érdekeik lelkiismeretes képviseletének követelménye állt. Ez a hozzáállás a külképviseleti munkatársakkal szemben támasztott korabeli elvárásokhoz is kapcsolódott. A „Darab-ügyben” kimutatható segítő aktivitásnak, lojalitásnak tehát számos egyéb példája 
is kiolvasható a konzulátusi dokumentumokból. Schefbeck Jakab István magatartása - benyomásom szerint - bizonyos esetekben mintha meghaladta volna a konzuli szerepkört: néha mint a magyar emigráns közösségnek menedéket nyújtó, gondoskodó „Atya” jelenik meg a szemünk elött. A winnipegi magyar konzul magatartásának beható ismerete, megértése azonban további kutatásokat igényel.

Az asszony megküzdési, problémamegoldási kísérletei semmilyen hatással nem voltak a kanadai hatóságok - a bevándorlási minisztérium, a vizsgálatot végzö bizottság vagy a bevándorlási biztos - tetteire, gyakorlataira. A döntnökök ügykezelési stratégiái az asszony és a konzul elvárásaitól függetlenül, teljes mértékben a törvényi előírásokhoz illeszkedtek. A párra az elmegyógyintézet hívhatta fel a bevándorlási hatóságok figyelmét, az elöírásoknak megfelelően jelentette az esetet. A minisztérium pedig szintén a jogszabályokhoz alkalmazkodva vizsgálatot indított, és végül a törvényekben foglaltakat követve döntést hozott. A winnipegi bevándorlási biztos szerepe a végrehajtási szakaszban került elötérbe. A határozatból az is kitünik, hogy a deportálás alapját nem a férfi eröszakos tette, betegeskedése (elmezavara, szifilisze) vagy esetleges majdani kiszolgáltatottságának veszélye jelentette, az asszony tehát hiába építette védekezését ezekre a tényezőkre. Bár a hatóságok számára nem volt érdektelen az, ami Kanadában történt a házaspárral, döntőnek mégis az országba való belépésük körülményei bizonyultak. Az, hogy érkezésükkor eleve a tiltott osztályba tartoztak: nem voltak földmüvesek és egészségesek sem, valószínúleg már mindketten szifilisszel fertőzötten léptek be az országba. Vagyis a bevándorlási minisztérium elsősorban azt szankcionálta, hogy megszegték a tiltott osztályokra vonatkozó törvényi tilalmat, mindeközben félrevezették a hatóságokat. A Darab házaspár esete azt is mutatja, hogy azok is a deportáltak sorsára juthattak, akiket nem sújtott a gazdasági világválság, akiket nem fenyegetett az, hogy közteherré válnak (a válság elsősorban az 1931-1933 közti időszakban „csapott le” a bevándorlókra).

Lényegében mindhárom érintett: a házaspár, a konzul és a bevándorlási hatóságok is „tették a dolgukat”, a rendelkezésükre álló mozgástér hatékony kihasználására összpontosítottak. Ebből a küzdelemből azonban óhatatlanul a hatóságok kerültek ki győztesként, a másik két félnek jóval korlátozottabbak voltak az érdekérvényesítési lehetőségei, eszközei.

\section{Epilógus}

A történet azonban mégsem ért véget a deportálással. 1931. július 29-én a konzul különös levelet kapott Darab Józsefnétől, azonban nem Magyarországról, hanem Saskatchewan központjából, Reginából. A nő bevallotta, hogy férjét Magyarországon gyógyíthatatlan betegnek minősítették, ő pedig újra kijött Kanadába, mégpedig 
illegális úton, szabályokat sértve: „másnak a nevén [...] az unoka nővérem neve alatt”, vagyis a rokona (Végh Mária) útlevelével. ${ }^{101}$ A levélírásra az sarkallta, hogy egy „ellensége” megtudta az országba bejutásának körülményeit, és feljelentette. Tehát újból a deportálás fenyegette. A konzult - ismét - arra kérte, akadályozza meg azt, hogy haza kelljen mennie, mivel ,én nem vétettem semit csak az uram miat kellett nekem is menni". A nő ekkor már elvált lehetett, mert levelét úgy írta alá, hogy Jelenik Júlia volt Darab Józsefné. ${ }^{102}$ Schefbeck Jakab István szükszavúan csak egy kérést fogalmazott meg Jelenik Júlia számára:

„[...] felkérem, hogy az útlevelet, amellyel újból kijött Kanadába és a landing kártyáját küldje be azonnal ezen hivatalnak. Mielőtt ezt a két okmányt nem kaptam kézhez, semmiféle nyilatkozatot nem tehetek." 103

\section{FELHASZNÁLT FORRÁSOK}

MNL OL K 139 (Winnipegi Konzulátus) 13. csomó, 1931, 1. tétel MNL OL K 128 (Montreali Főkonzulátus) 2. csomó, 1932, I/2. tétel

Bán D. András - Diószegi László - Fejős Zoltán - Romsics Ignác - Vinnai Győző (szerk.): Magyarok kisebbségben és szórványban. A Magyar Miniszterelnökség Nemzetiségi és Kisebbségi Osztályának válogatott iratai, 1919-1944. Budapest: Teleki László Alapítvány, 1995.

Kanadába utazók részére szükséges tudnivalók és felvilágositások. Budapest: $\mathrm{Cu}-$ nard Line, [1924]

Immigration Act (1910) https://pier21.ca/research/immigration-history/immigration-act-1910 (Letöltés ideje: 2021. március 14.)

Magyarországi Rendeletek Tára 1920. Budapest: Magyar Kir. Belügyminisztérium, 1920.

Külügyi Közlöny, 1922, 1925, 1927, 1928, 1934

Winnipeg Free Press, 1939

\section{FELHASZNÁLT IRODALOM}

Abrams, Gary William David: Prince Albert: the First Century 1866-1966. Saskatoon: Modern Press, 1976.

\footnotetext{
101 A szabályok szerint a deportáltak nem térhettek vissza Kanadába.

${ }^{102}$ MNL OL K 139, 13. csomó, 1931, 1. tétel, 3222/D, 2-4. Fontos körülmény, hogy levelét egy kórházból írta, ennek oka azonban nem ismert.

${ }^{103}$ MNL OL K 139, 13. csomó, 1931, 1. tétel, 3222/D, 1. Az ügy kimenetele, az, hogy vajon másodjára is deportálták-e, egyelöre nem ismert.
} 
Boross Ottilia - Pléh Csaba (szerk.): Bevezetés a pszichológiába: olvasmányok és feladatok a lélektan alapkérdéseinek tanulmányozásához. Budapest: Osiris, 2004.

Dreisziger F. Nándor: A Decade of Setbacks: The 1930's. In: uő (ed.): Struggle and Hope. The Hungarian-Canadian Experience. Toronto: McClelland \& Stewart, 1982. 139-168.

Dreisziger F. Nándor: Immigrant Lives and Lifestyles in Canada, 1924-1939. Hungarian Studies Review, No. 1. Spring/1981. 61-83.

Dreisziger F. Nándor: Years of Growth and Change, 1918-1929. In: Dreisziger F. Nándor (ed.): Struggle and Hope. The Hungarian-Canadian Experience. Toronto: McClelland \& Stewart, 1982. 94-138.

Friesen, Gerald: The Canadian prairies: a history. Toronto: University of Toronto Press, 1987.

Kósa, John: Land of Choice. The Hungarians in Canada. Toronto: University of Toronto Press, 1957.

Kovács, Martin L.: The Saskatchewan Era 1885-1914. In: Dreisziger F. Nándor (ed.): Struggle and Hope. The Hungarian-Canadian Experience. Toronto: McClelland \& Stewart, 1982. 61-93.

Kulcsár Beáta: Adaptációs kísérletek Kanadában. Egy magyar emigráns küzdelmei az 1920-as évek második felében. Pro Minoritate, 2021/1. 3-18.

Patrias, Carmela: Patriots and Proletarians. Politicizing Hungarian Immigrants in Interwar Canada. Montreal: McGill-Queen's University Press, 1994.

Pritz Pál: A bécsi követség története a két háború között. Külügyi Szemle, 2013/2. $55-68$.

Puskás Julianna: Kelet-Európából az USA-ba vándorlás folyamata 1861-1924. Történelmi Szemle, 1984/1-2. 145-164.

Puskás Julianna: Migráció Kelet-Közép-Európában a 19. és 20. században. Regio, 1991/4. 22-48.

Rényi József: A külügyi közigazgatás. Budapest: Franklin, 1912.

Roberts, Barbara: Whence They Came: Deportation from Canada 1900-1935. Ottawa: University of Ottawa Press, 1988.

Robertson, John Palmerston: Political Manual of the Province of Manitoba and the North-West Territories. Winnipeg: Call Print. Co., 1887.

Ruzsa Jenő: A kanadai magyarság története. Toronto: Ruzsa Jenő ev. lelkész, 1940. Mental Health Services. The Encyclopedia of Saskatchewan.

https://esask.uregina.ca/entry/mental_health_services.jsp (Letöltés ideje: 2021. március 14.)

Tisza Tímea: Új trendek és kihívások a szexuális úton terjedő fertőzések területén. Magyar Tudomány, 2020/3. 329-342. 